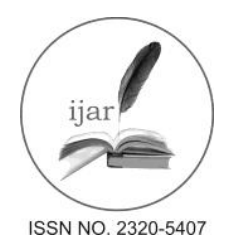

Journal homepage: http://www.journalijar.com
Journal DOI: 10.21474/IJAR01

INTERNATIONAL JOURNAL

OF ADVANCED RESEARCH

RESEARCH ARTICLE

\title{
SOCIAL EXCLUSION AND INCLUSION: IMPORTANT STEPS TOWARDS LONG STANDING STRUGGLE FOR SOCIAL INCLUSION.
}

\author{
Dr. Jitendra Kumar Gond ${ }^{1} \&$ Ramanpreet Kaur ${ }^{2}$. \\ 1. Dr. Jitendra Kumar Gond, Assistant Professor in Sociology, Post Graduate Government College, Sec -11, \\ Chandigarh, India. \\ 2. Ramanpreet Kaur, Research Scholar, Deptt. of Psychology, Panjab University, Chandigarh, India.
}

\section{Manuscript Info}

Manuscript History:

Received: 19 March 2016

Final Accepted: 16 April 2016

Published Online: May 2016

Key words:

Social Exclusion, Social Inclusion, Poverty,.

*Corresponding Author

Dr. Jitendra Kumar Gond.

\begin{abstract}
The aim of this paper is to make a contribution to the discourse on ostensibly unfair practice of social exclusion and examine the exclusionary nature of Indian society expressing its character sometimes in the name of religion, sometimes in the name of culture and sometimes in the garb of nationalism. The equality of opportunity and resources remains elusive despite the affirmative action by the Govt. of India and the vulnerable segments of society remain on the receiving end of injustices in the form of social boycott or exclusion. The exclusion of the poor from participation in social activities and denial of opportunities to them remain another focus of the paper. In addition, this paper makes an attempt to unravel the psychological and sociological causal factors as well as the effects of social exclusion on the psyche of those excluded. This paper is formulated with the agenda that the ideas conveyed through the paper will have a dual impact on policy makersone, to ensure better understanding of social exclusion and two, to stimulate a discussion that will aid the policy makers to address this vital social issue to promote social inclusion and inclusive growth.
\end{abstract}

We, the People of India having solemnly resolved to constitute India into a Sovereign, Socialist, Secular, Democratic, Republic and to secure to all its citizens; Justice, social, economic, political; Liberty of thought, expression, belief, faith and worship; Equality of status and opportunity; and to promote among them all; Fraternity, assuring the dignity of the individual and the unity and integrity of the nation; In our Constituent Assembly this, twenty sixth day of November 1949 do hereby Adopt, Enact and Give to ourselves this Constitution.

Copy Right,IJAR, 2016..All rights reserved...

\section{Introduction:-}

The Preamble lists four cardinal objectives that the constitution is committed to secure for all its citizens namely justice, liberty, equality and fraternity. Social exclusion stands as a challenge to this process. Social exclusion in common sense is understood as a lack of belonging or of acceptance and a denial of recognition. The credit of authorship of the expression- social exclusion- goes to René Lenoir (1974). It is a multidimensional evil operating on social, political, economic and cultural levels. It is the product of unequal power distribution in the society and ruptures the relationships between people and society eventually leading to a lack of social participation and social integration. 


\section{European Union defines it as:-}

"Certain individuals are pushed to the edge of society and prevented from participating fully by virtue of their poverty, or lack of basic competencies and lifelong learning opportunities, or as a result of discrimination. This distances them from job, income and education opportunities as well as social and community networks and activities. They have little access to power and decision-making bodies and thus often feel powerless and unable to take control over the decisions that affect their day to day live". (European Commission in April 2005).

Silver and Miller (2003) are of the view that social exclusion connotes a broader, more holistic meaning and implication of deprivation, in contrast to poverty, which according to them is exclusively economic, material, or resource-based. It is a violation of social justice. It undermines social solidarity and integration.

Poverty, which has its tangible material dimension and an immaterial dimension- marginalization- is not the only underlying cause of social exclusion and deprivation in India. Caste, religion, region, disability status, migrant status, age, skin complexion, race, ethnicity, gender, mental and physical health status, the means of livelihood, sexual orientation or any other stigmatized markers, confer a mark on people that excludes them from a range of activities and opportunities. Social inequalities are a hallmark of the society riddled with social exclusion. 'Social inequalities' can be defined as the constraints on opportunity. They are based on various status ascriptions or social attributes such as gender, age, caste, religion, race, ethnicity, and place of residence etc.

Social exclusion can be defined as "discrimination against culturally defined groups" (de Haan, 1997, 2007). Social exclusion presents "an important dimension of the experience of certain groups of being somehow 'set apart' or 'locked out' of participation in social life" (Kabeer, 2000). It helps us to understand "the various institutional mechanisms through which resources are allocated ...operate in such a way as to systematically deny particular groups of people the resources and recognition which would allow them to participate fully in the life of that society" (Kabeer, 2000).

An European Commission document named "Observatory on National Policies to Combat Social Exclusion, Report of 1992" defines social exclusion "in relation to social rights of citizens- to a certain basic standard of living and to participation in the major social and occupational opportunities of the society" (Gore, et al, 1995).

Social exclusion occurs "when some groups are discriminated against either because of perception or prejudice" (Darity, 2012). Inferiority of these groups is attributed to either genetics or the cultural norms of the group. But none of these have any empirical basis and it amounts to "blaming the victim" (Darity, 2012). The prejudice held by perpetrators is often driven by 'material' interest in sharing resources and is also reflected in what is called unfavourable inclusion - in which some groups culturally different from the rest, are forced to exclusively engage in some kind of inferior, un-respected, low paid and menial activities, while being kept away from superior, profitable, socially respected and well paid activities (Sen, 2000).

Distinguishing social exclusion from social isolation, it is worth noticing that social isolation is the phenomenon of non-participation by an individual or a group while social exclusion involves denial of acceptance for reasons which are beyond the control of those to whom it is meted out to. But it may also be the case that an individual or a group may withdraw from participation in the wider society on account of the experience of hostility and discrimination they were subjected to.

Social exclusion is a function of the societal interrelations and institutions that operate with an aim to exclude, discriminate, isolate and deprive certain groups or sections of the society on the bases of their identity such as caste, ethnicity and religion (Thorat \& Louis, 2003).

Social exclusion is a distressing experience to its victims as it threatens the fulfillment of basic human needs. It leads to of our need for belongingness, our need control over our social environment and our needs for self-esteem and a meaningful existence (Williams 2007; Baumeister \& Leary 1995). According to Byrne (1999), "exclusion is a procedure to break the societal networking and collective bonds among the individual and groups of the society". It prohibits the involvement of people in activities of society and hinders them from enjoying all kind of resources, sociability, recognition, and self-identity. 


\section{Bases of Social Exclusion:-}

The menace of social exclusion and discrimination has been attracting considerable attention in academic debates and social science research since last few years (World Bank, 2011; 2013). Despite the constitutional safeguards for marginalized groups, discrimination still operates in various subtle forms. To study the phenomenon of social exclusion it is imperative to identify the groups that are known to have been or are likely to be socially excluded on the basis of their specific ascriptions or attributes. Next, the mechanisms of their exclusion can be examined and feasible ways of increasing their inclusion in the mainstream can be devised.

Discrimination in the labour market dovetails with the denial of equal economic rights to the persons belonging to the segregated and discriminated groups (Mamgain, 2014).

Gender-based discrimination and exclusion is a phenomenon observed all over the world. It has been extensively studied by researchers in its various forms such as sexual division of work, differences in wages for men and women, and discrimination in hiring process, placements and promotions. Papola and Sahu (2012) asserted that a woman's chance of getting a regular job in the organised sector is 0.67 of a male worker. They also insisted that a woman worker on an average earns 60 per cent of the wage of a male worker.

In India the social exclusion and discrimination is entwined with the social institution of caste which gives unequal rights to individuals not on the basis of their merit but simply by their birth in a certain caste. The Scheduled Castes (SCs) and Scheduled Tribes (STs) together constitute nearly one-fourth of the Indian population continue to lag behind the other social groups in various indicators of development (Mamgain, 2013). The Scheduled Castes or untouchables find their place at the bottom of the hierarchy of caste system in Indian society and they have suffered because of customary rules and they were denied rights to property and education (Thorat \& Newman, 2010). There is ostensible segregation in residential units on the basis of caste (Vithayathil \& Singh, 2012).

A field experiment by Thorat et al. (2008) revealed how Scheduled Castes and Muslim candidates who are equally or better qualified than higher caste candidates are less likely to be hired by employers in the formal sector in India. The managers in private sector come with certain sets of stereotypes which makes it difficult these candidates to succeed in the competition they are fighting (Jodhka \& Newman, 2007).

While reviewing the literature on social exclusion, one thing particularly stands out- the continuum of disadvantage: beginning from primarily economic and moving towards primarily cultural (in the form of "what you have' to 'who you are') (Deshpande, 2013). Somewhere in midst of these lie the hybrid forms of injustices for those social groups for whom economic disadvantage is intertwined with culture based disadvantage. One example of bivalent group in India is gender and caste. A woman coming from a Dalit background might face exclusion on account of being a woman as well as being a Scheduled Caste. Some policymakers and academic researchers hold the view that the significance of caste has greatly diminished as India has urbanized (Prasad, 2010). On the other hand, social science research on caste in the urban Indian context suggests that caste remains highly relevant in schooling decisions, educational outcomes and securing jobs (Munshi \& Rosenzweig 2006; Thorat \& Newman 2010).

When it comes to exclusion of sex workers, their work is associated with high levels of social stigma, even more in case of women (Scambler, 2007). Stigmatization from various agents of society such as clients, general public, and police is the background reality of their lives (Sanders, 2007b). This leads to reduced contact with society and hesitance to avail health care services, higher levels of stress leading to mental health problems, and feelings of isolation and eventually social exclusion (Cusick \& Berney, 2005).

There is one dimension to social exclusion which lies outside the purview of economic deprivation and social discrimination- the spatial disadvantage (where you are). Spatial disadvantage may exist because of remoteness and isolation of a location making it difficult for its inhabitants to be included in social processes. Criminality and drug abuse sometimes characterise the territorially excluded neighbourhoods (Beall, 2002).

\section{Policies for Inclusion and Equality:-}

Policy-makers now and then devise plans and programmes to improve the lot of the depressed classes and marginalized sections. But policies aiming to target social exclusion can only be effective if they first understand the nature of disadvantage and the source of exclusion. In order to design remedies for social exclusion, the groups 
which are facing economic exclusion, state policies need to work on different platform as compared to for the groups which are excluded for cultural reasons.

National Integration has been so central to the policy makers and torch-bearers of this nation that National Integration Council was set up by the then Prime Minister, Mr. Jawaharlal Nehru, who convened National Integration Conference in September-October, 1961 with an agenda to devise means to combat the evils of communalism, casteism, regionalism, linguism and narrow-mindedness, and to formulate definite conclusions in order to give a lead to the country. In midst of the cacophony of discourse on nationalism and other domestic issues in India, one can expect an issue of such vital importance as social exclusion is, to reserve some space in minds of people. Social exclusion is detrimental to national integration and has to be combated with in order to ensure all round growth and equality for all segments of society.

\section{The 12th Five Year Plan has the following to say about inclusiveness:-}

"Inclusive growth should result in lower incidence of poverty, broad-based and significant improvement in health outcomes, universal access for children to school, increased access to higher education and improved standards of education, including skill development. It should also be reflected in better opportunities for both wage employment and livelihood, and in improvement in provision of basic amenities like water, electricity, roads, sanitation and housing. Particular attention needs to be paid to the needs of the SC/ST and OBC population. Women and children constitute a group which accounts for $70 \%$ of the population and deserves special attention in terms of the reach of relevant schemes in many sectors. Minorities and other excluded groups also need special programmes to bring them into the mainstream." (Planning Commission, 2011).

National Rural Employment Guarantee Act (2005), another flagship programme of the government, later named as Mahatma Gandhi National Rural Employment Guarantee Act (MGNREGA) aims to tackle exclusion in more ways than one. The programme was initially launched in the 200 most backward districts in the country (now extended to the whole country) with low agricultural productivity, high incidence of poverty, higher concentration of SC-ST people, geographical isolation and other such indices. Banerjee and Saha (2010) reported that the programme has proved to be inclusionary to a large extent in the Naxal affected districts, which are among the poorest and the most backward in the nation.

\section{Psychosocial Impact of Social Exclusion:-}

In a series of experimental researches by Twenge et al. (2001), it was observed that when social exclusion was acted out against participants, they behaved more aggressively. When the participants were told that they would end up alone later in life or that other participants had rejected/them, the participants exhibited more aggression. These participants issued a more negative job evaluation about someone who insulted them. Interestingly, the participants were not as aggressive towards someone who praised them.

Studies suggest that exclusion may impair cognitive forms of intelligence in the excluded. Significant and large decrease in intelligent thought were noticed in participants when they were told that they were likely to end up alone in life (Baumeister et al., 2002).

Impairments in mental health are seen in children and adolescents who are rejected by their peers. These impairments can persist across the span of development (Ladd 2006; Ladd \& Troop-Gordon, 2003; Prinstein \& Aikins, 2004).

Social boycott or ostracism leaves a negative emotional impact on its targets (Williams, 2007; Eisenberger et al., 2003 ; Baumeister \& Leary, 1995), as well as on its sources (Legate et al., 2013; Poulson and Kashy, 2011; Ciarocco et al., 2001).

An individual's well-being is jeopardized when they encounter threats to optimal levels of social acceptance and experience social exclusion. Researchers have established that individuals who experience social exclusion or rejection exhibit a variety of cognitive, affective, and somatic ill-effects (Baumeister et al., 2005; Zadro et al., 2005; Pickett et al., 2004). 


\section{The need of the hour- Social Inclusion:-}

The concept of inclusion can be interpreted as the involvement of the entire population in the activities of society, performances of the social system. As a society moves towards achievement of social inclusion, the segment of the society that does not or only marginally participates in the societal activities disappears (Luhman, 1990). Inclusive growth is the growth for all, ensuring and securing opportunities for socially and financially excluded or deprived sections. Social inclusion figures as a central tenet in the World Bank Group's dual goals of ending extreme poverty by 2030 and promoting shared prosperity. The World Bank defines social inclusion as "the process of improving the terms for individuals and groups to take part in society". Social inclusion attempts to empower the disfranchised sections of society to have their say and voice their opinions in matters that affect their lives and to facilitate them to gain advantage from expanding global opportunities. It also ensures that they have equal access to markets, resources, services and social spaces.

\section{Conclusion:-}

Despite the constitutional safeguards and provisions for disfranchised, marginalized and deprived groups, discrimination, ostracism, exclusion are operational in Indian society in subtle forms. To a keen observer, it is evident that India is quite a distance away from achieving inclusiveness. We boast of a seven percent growth rate, but in order to reap the benefits of economic growth, we need to make sure that the growth we are making is inclusive. Sensitization of society towards the plight of deprived along with an attempt to de-stigmatization is warranted. And it is imperative that policy making shall aim not only to address economic but also social, cultural and political exclusion in an effective manner.

\section{References:-}

1. Baumeister, R. F., Twenge, J. M., \& Nuss, C. K. (2002). Effects of social exclusion on cognitive processes: Anticipated aloneness reduces intelligent thought. Journal of Personality and Social Psychology, 83(4), 817827. http://dx.doi.org/10.1037/0022-3514.83.4.817

2. Baumeister, R.F, DeWall, C.N., Ciarocco, N. J., \& Twenge, J.M.(2005).Social exclusion impairs selfregulation. Journal of Personality and Social Psychology, 88, 589-604.

3. Baumeister, R.F. \& Leary, M.R. (1995). The need to belong: Desire for interpersonal attachments as a fundamental human motivation. Psychological Bulletin, 117, 497-529.

4. Beall, J. (2002) Globalisation and Social Exclusion in Cities: Framing the Debate with Lessons from Africa and Asia, DESTIN Working Paper Series 02/27, London: London School of Economics.

5. Byrne, (1999). Rural development: Putting the last first. Prentice Hall: New Jersey.

6. De Haan, A. (1997). Poverty and Social Exclusion: A Comparison of Debates on Deprivation, Working Paper No. 2, Poverty Research Unit at Sussex. Brighton: University of Sussex.

7. Ciarocco, N. J., Sommer, K. L., \& Baumeister, R. F. (2001). Ostracism and ego depletion: The strain of silence. Personality and Social Psychology Bulletin, 27, 1156-1163. doi:10.1177/0146167201279008

8. Cusick, L. \& Berney, L. (2005). Prioritizing punitive responses over public health: commentary on the Home Office consultation document Paying the Price. Critical Social Policy. 25(4), 596-606.

9. De Haan, A .(2007). Labelling Works: The Language and Politics of Caste and Tribe in India', in Rosalind Eyben and Joy Moncrieffe (eds.) The Power of Labelling: How People are Categorised and How it Matters, London: Earthscan.

10. Deshpande, A. (2013). Exclusion and Inclusive Growth. UNDP, published in New Delhi.

11. Eisenberger, N.I., Lieberman, M.D., \& Williams, K.D. (2003).Does rejection hurt? An fMRI study of social exclusion. Science, 10(302), 290-292.

12. European Commission, (2006). Portfolio of overarching indicators and streamlined social inclusion, pensions and health portfolios. Brussels.

13. Jodhka, S.S. \& Newman, K.S. (2007). In the Name of Globalisation: Meritocracy, Productivity and the Hidden Language of Caste. Economic and Political Weekly, 42 (41), 4125-4132.

14. Kabeer, N.(2000). Social Exclusion, Poverty and Discrimination: Towards an analytical framework. IDS Bulletin, 31(4), 83-97.

15. Khan, S., Combaz, E. \& McAslan Fraser, E. (2015). Social exclusion: topic guide. Revised edition. Birmingham, UK: GSDRC, University of Birmingham.

16. Ingole, K.S.(2011). A critical study of social exclusion \& its implication. In Excluded People in India: Problems and Prospect. Rajas Parchure, S.N.Tripathy, J.R.Ambewadekar (Eds.) .Mangalam Publishers and Distributers: Delhi. 
17. Ladd, G. W. (2006). Peer rejection, aggressive or withdrawn behavior, and psychological maladjustment from ages 5 to 12: an examination of four predictive models. Child Development, 77, 822-846.

18. Ladd, G. W., \& Troop-Gordon, W. (2003). The role of chronic peer difficulties in the development of children's psychological adjustment problems. Child Development, 74, 1344-1367.

19. Lenoir, R. (1974/1989). Les Exclus: Un Francais sur Dix. Paris: Editions du Seuil.

20. Legate, N., DeHaan C. R., Weinstein N., \& Ryan R. M. (2013). Hurting you hurts me too: The psychological costs of complying with ostracism. Psychological Science, 24, 583-588. 10.1177/0956797612457951

21. Luhman, N. (1990). Political Theory in the Welfare State. Berlin, New York: Walter de Gruyter.

22. Mamgain, R. P. (2013). Situating Scheduled Castes and Scheduled Tribes in the Post-2015 Development Framework. Oxfam India Working Papers Series, OIWPS-XIX, June.

23. Mamgain, R. P. (2014). Social exclusion, discrimination and atrocities on scheduled castes in india: the worrying spots and future challenges. Journal of Economic \& Social Development, 10(1), 17-30.

24. Munshi, K. \& Rosenzweig, M. (2006). Traditional institutions meet the modern world: caste, gender, and schooling choice in a globalizing economy. American Economic Review,96(4), 1225---1252.

25. Planning Commission.(2011). Report of the Sub-group-I on Perspective Planning for Empowerment Scheduled Castes during the Twelfth Five Year Plan, New Delhi, August.

26. Pickett, C.L., Gardner, W.L., \& Knowles, M. (2004). Getting a cue: The need to belong and enhanced sensitivity to social cues. Personality and Social Psychology Bulletin, 30, 1095-1107.

27. Prinstein, M. J., \& Aikins, J. W. (2004). Cognitive moderators of the longitudinal association between peer rejection and adolescent depressive symptoms. Journal of Abnormal Child Psychology, 32, 147-158.

28. Poulsen, J. R., \& Kashy, D. A. (2011). Two sides of the ostracism coin: How sources and targets of social exclusion perceive themselves and one another. Group Processes \& Intergroup Relations. Advance online publication. doi:10.1177/1368430211430517

29. Prasad, C.B. (2010). New Order. Himal South Asian.

30. Scambler, G. (2007) Sex Work Stigma: Opportunist Migrants in London. Sociology, 41(6), 1079-96.

31. Sanders, T. (2007b). Protecting the health and safety of female sex workers: the responsibility of all. BJOG, 114(7), 791-793.

32. Sen, A. (2000), Social Exclusion: Concept, Application and Scrutiny, Working Paper, Social Development Paper No. 1, Manila, Asian Development Bank, June.

33. Silver, H. \& Miller, S. M. (2003). Social exclusion: the European approach to social disadvantage. Indicators, 2, $1-17$.

34. Thorat, S., Attewell, P.\& Rizvi, F.(2008-a). The Legacy of Social Exclusion: A Correspondence Study of Job Discrimination in India, in Labour Market Discrimination and Urban Sector. Research Series 1, Volume 1, Indian Institute of Dalit Studies, New Delhi.

35. Thorat, S.K. \& Louis, P. (2003). Caste, Ethnicity and Religion: An Overview of Exclusion / Discrimination and Deprivation', Concept paper for DFID, Delhi.

36. Thorat, S. \& Newman, K.S.(2010). Introduction: Concepts, Consequences and Remedies, in Sukhadeo Thorat and Katherine S. Newman (eds) op cit.

37. Thorat, S. \& Newman, K. (2010). Blocked by Caste- Economic Discrimination in Modern India. Oxford University Press: New Delhi.

38. Twenge, J. M., Baumeister, R.F., Tice, D. M., Stucke, T. S. (2001). If you can't join them, beat them: Effects of social exclusion on aggressive behavior. Journal of Personality and Social Psychology, 81(6), 1058-1059. http://dx.doi.org/10.1037/0022-3514.81.6.1058

39. Vithayathil, T. \& Singh, G. (2012). Spaces of Discrimination. Economic \& Political Weekly,47(37), 60-66.

40. Williams, K.D. (2007).Ostracism. Annual Review of Psychology, 58, 425-452.

41. World Bank.(2011). Poverty and Social Exclusion in India. The World Bank : Washington DC.

42. World Bank.(2013). Inclusion Matters: The Foundation for Shared Prosperity. The World Bank: Washington DC.

43. Zadro, L.,Williams, K., \& Richardson, R.(2005). Riding the 'O' train: Comparing the effects of ostracism and verbal dispute on targets and sources. Group Processes and Intergroup Relations, 8 (2), 125-143. 